\title{
Partisipasi Masyarakat Dalam Pembangunan Kampung
}

\author{
Andri Irawan \\ Ilmu Administrasi Publik \\ Sekolah Tinggi Ilmu Administrasi Karya Dharma Merauke \\ e-mail : andwan20@gmail.com
}

Edy Sunandar

Ilmu Administrasi Publik

Sekolah Tinggi Ilmu Administrasi Karya Dharma Merauke

Received: 25 September 2020; Revised: 10 Oktober 2020; Accepted : 15 November 2020;

Published : December 2020; Available online : December 2020.

\begin{abstract}
Community participation is a component that plays a very important role in implementing development in the village, because community involvement will have an impact on the benefits of development results for the village community, starting from planning, implementing, and utilizing the results of development in the village. The results showed that the coverage indicators were not implemented properly. Village development programs were only discussed by a few elements and did not involve all elements of society. Then there is still minimal space given by the village government to the community. In addition, the livelihoods of local people who require going to fields and forests make it difficult for the village government to empower them so that indicators of empowerment are still not visible there. Obstacles to participation in the community related to the development of Kampung Kamangi include the lack of public awareness of the importance of being involved in any development in the village, and the lack of space provided by the village government to the people who will participate.
\end{abstract}

Keywords: Community Participation, Village Development

\section{Pendahuluan}

Berdasarkan Undang-Undang

Nomor 6 Tahun 2014 tentang Desa atau yang disebut dengan nama lain (untuk wilayah Papua disebut kampung), pada Pasal 1 Ayat ke 8 menyebutkan bahwa pembangunan desa adalah upaya peningkatan kualitas hidup dan kehidupan untuk sebesar-besarnya kesejahteraan masyarakat desa. Untuk mewujudkan ketentuan Peraturan perundang-undangan tersebut perlu 
peran aktif dari pemerintah serta melibatkan masyarakat dalam setiap proses pembangunan.

Oleh karena itu, keberhasilan pembangunan tidak semata-mata mengandalkan pemerintah karena peran seluruh komponen masyarakat juga mempengaruhi keberhasilan dari suatu pembangunan, peran pemerintah saat ini hanya sebagai fasilitator, regulator, motivator dalam penyediaan prasarana publik. Masyarakatlah sebagai pelaku utama pembangunan, dimana keterlibatan partisipasi masyarakat dalam pelaksanaan pembangunan yang dianggap dapat mengatasi kesenjangan pembangunan yang terjadi, namun terkadang tujuan yang ingin dicapai oleh pemerintah daerah tidak seiring dan sejalan dengan tujuan yang ingin dicapai oleh masyarakat.

Pembangunan dalam sebuah kampung terdiri dari pembangunan fisik dan pembangunan non fisik. Pembanguan fisik yaitu terdiri dari infrastruktur seperti pembangunan rumah bantuan, perbaikan sumur Bor, MCK, pembangunan fasilitas air bersih, pembuatan jalan/ jalan sawah, dan fasilitas listrik. Sedangkan pembangunan non fisik seperti pembentukan kelompok-kelompok peramu kebun, kelompok usaha peternak ayam, dan kelompok-kelompok masyarakat lainnya. Sehingga, agar tujuan pembangunan tersebut dapat terwujud maka peran serta dan kerja sama dari seluruh masyarakat yang ada sangat diperlukan sekali, karena salah satu faktor yang menentukan dalam terlaksananya suatu pembangunan adalah faktor manusia itu sendiri.

Dalam pelaksanaan pembangunan, partisipasi masyarakat sangat diharapkan dalam setiap tahapan pembangunan yang dimulai dari tahap perencanaan, tahap pelaksanaan, tahap pemanfaatan dan tahap evaluasi. Melalui pembangunan yang berbasis partisipasi masyarakat ini akan dapat dilaksanakan pembangunan daerah yang benar-benar sesuai dengan kebutuhan dan aspirasi masyarakat.

Seperti yang dikatakan oleh (Irawan, 2019) bahwa partisipasi masyarakat merupakan satu komponen yang memegang peranan sangat penting dalam melaksanakan pembangunan di kampung, sebab dengan pelibatan masyarakat yang murni akan berdampak pada kemanfaatan hasil pembangunan terhadap masyarakat kampung mulai dari perencanaan, pelaksanaan, dan pemanfaatan hasil pembangunan di kampung. 
Lebih jauh, partisipasi masyarakat adalah keikutsertaaan masyarakat secara sukarela yang didasari oleh determinan dan kesadaran diri masyarakat itu sendiri dalam program pembangunan.

$$
\text { Begitu pentingnya }
$$

peningkatan partisipasi masyarakat di kampung, membuat peneliti tertarik dan ingin mendeskripsikan dan menganalisis partisipasi masyarakat dalam pembangunan kampung, kendalakendala apa yang dihadapi pemerintah kampung dalam meningkatkan partisipasi masyarakat serta upaya apa yang dilakukan oleh pemerintah kampung dalam meningkatkan partisipasi masyarakat Kampung Kamangi Kabupaten Merauke.

Metode Penelitian

Jenis penelitian ini adalah deskriptif dengan menggunakan pendekatan kualitatif. Data diperoleh melalui informan kunci yang ditentukan secara bertujuan (purposive). Ada pun yang ditetapkan sebagai informan kunci adalah Kepala Kampung dan aparat Pemerintahan Kampung, pengurus Program Pembangunan Kampung serta beberapa tokoh masyarakat yang ditentukan secara snow ball. Disamping itu, studi dokumentasi dan observasi juga digunakan untuk menjaring data yang relevan. Teknik analisis data dalam penelitian ini menggunakan tiga aktifitas dalam analisis data yaitu: Data Condensation, Data Display, dan Drawing and Verifying Conclusions (Miles, Huberman, and Saldana : 2014).

Lokasi penelitian dilakukan di Kampung Kamangi Distrik Tanah Miring. Lokasi penelitian tersebut dipilih karena Kampung Kamangi merupakan Kampung yang baru di mekarkan pada akhir tahun 2015 sehingga masih perlu perhatian, bagaimana dan seperti apa kondisi warga dan pembangunannya. Serta kehidupan warga yang masih sangat tergantung dengan bantuan-bantuan pemerintah daerah dan pekerjaan warganya yang bersifat tradisional seperti mencari hasil hutan, berburu dan mencari ikan (tradisi meramu).

\section{Konsep Partisipasi Masyarakat}

Sumaryadi, (2010: 46) mengatakan bahwa partisipasi berarti peran serta seseorang atau kelompok masyarakat dalam proses pembangunan baik dalam bentuk pernyataan maupun dalam bentuk kegiatan dengan memberi masukan pikiran, tenaga, waktu, keahlian, modal dan atau materi, serta ikut memanfaatkan dan menikmati hasilhasil pembangunan. Sedangkan Cohen dan Uphoff dalam Astuti (2011: 61-63) membedakan patisipasi menjadi empat 
jenis, yaitu pertama, partisipasi dalam pengambilan keputusan. Kedua, partisipasi dalam pelaksanaan. Ketiga, partisipasi dalam pengambilan pemanfaatan. Dan Keempat, partisipasi dalam evaluasi.

$$
\text { Conyer dalam Soetomo }
$$

(2008), mengemukakan partisipasi masyarakat adalah keikutsertaaan masyarakat secara sukarela yang didasari oleh determinan dan kesadaran diri masyarakat itu sendiri dalam program pembangunan. Ada lima cara untuk melibatkan keikutsertaan masyarakat yaitu: 1) Survei dan konsultasi lokal untuk memperoleh data dan informasi yang diperlukan. 2) Memanfaatkan petugas lapangan, agar sambil melakukan tugasnya sebagai agen pembaharu juga menyerap berbagai informasi yang dibutuhkan dalam perencanaan. 3) Perencanaan yang bersifat desentralisasi agar lebih memberikan peluang yang semakin besar kepada masyarakat untuk berpartisipasi. 4) Perencanaan melalui pemerintah lokal. 5) Menggunakan strategi pembangunan komunitas (community development).

$\begin{array}{rrr}\text { Partisipasi } & \text { secara } & \text { umum } \\ \text { merupakan peran } & \text { serta } & \text { atau }\end{array}$
keikutsertaan/keterlibatan seseorang secara perseorangan atau berkelompok dalam suatu kegiatan. Dalam rangka memperoleh hasil yang optimal, dikatakan oleh Mikkelsen (2011:56) bahwa dibutuhkan pendekatan yang mensinergikan potensi masyarakat. Pendekatan ini memerlukan perencanaan matang yang mendorong peran serta aktif masyarakat. Lebih lanjut Mikkelsen mengartikan partisipasi, antara lain : “(a) partisipasi adalah kontribusi sukarela dari masyarakat kepada proyek tanpa ikut serta dalam pengambilan keputusan. (b) partisipasi adalah pemekaan (membuat peka) pihak masyarakat untuk menanggapi proyekproyek pembangunan. partisipasi adalah suatu proses yang aktif, yang mengandung arti bahwa orang atau kelompok yang terkait, mengambil inisiatif dan menggunakan kebebasannya untuk melakukan hal itu. (d) partisipasi adalah pemantapan dialog antara masyarakat setempat dengan para staf yang melakukan persiapan, pelaksanaan, monitoring proyek, agar supaya memperoleh informasi mengenai konteks lokal, dan dampak-dampak sosial. (e) partisipasi adalah keterlibatan sukarela oleh masyarakat dalam perubahan yang ditentukan sendiri. (f) partisipasi adalah keterlibatan masyarakat dalam pembangunan diri, kehidupan, dan lingkungan mereka." 
Secara umum partisipasi dapat dilihat dari bentuk keikutertaan masyarakat yang dapat dilihat dari bentuk nyata maupun tidak nyata. Sebagai bentuk keikutsertaan masyarakat/kelompok terdapat beberapa wujud dari partisipasi. Seperti yang diungkapkan oleh Isbandi (2007) bahwa partisipasi masyarakat adalah keikutsertaan masyarakat dalam proses pengidentifikasian masalah dan potensi yang ada di masyarakat, pemilihan dan pengambilan keputusan tentang alternative solusi untukmenangani masalah, pelaksanaan upaya mengatasi masalah, dan keterlibatan masyarakat dalam proses mengevaluasi perubahan yang terjadi.

Partisipasi masyarakat dalam pembangunan merupakan hal yang sangat penting ketika diletakkan atas dasar keyakinan bahwa masyarakatlah yang paling tahu apa yang mereka butuhkan dan masyarakat jugalah permasalahan yang mereka hadapi. Namun kenyataan yang masih terlihat bahwa di setiap program pembangunan, partisipasi masyarakat belum terlihat secara keseluruhan.

$$
\text { Luigi Bobbio }
$$

mengartikan bahwa partisipasi adalah di mana warga negara terlibat di dalam proses desain suatu kebijakan.
Partisipasi publik dengan demikian merupakan alat prosedural yang memungkinkan pembuat kebijakan untuk memasukkan aktor baru (yaitu warga negara) dalam jaringan kebijakan dan mempercayakan beberapa kepada mereka.

Slamet (2003) menyatakan bahwa tumbuh dan berkembangnya partisipasi masyarakat dalam pembangunan, sangat ditentukan oleh tiga unsur pokokyaitu: (a) Adanya kesempatan yang di berikan kepada masyarakat, untuk berpartisipasi. (b) Adanya kemauan masyarakat untuk berpartisipasi (c) Adanya kemampuan masyarakat untuk berpartisipasi.

Selain itu, ada tiga prinsip dasar dalam menumbuhkan partisipasi masyarakat kampung agar ikut serta dalam pembangunan: (1) Learning proces (learning by doing); proses kegiatan dengan melakukan aktifitas proyek dan sekaligus mengamati, menganalisa kebutuhan dan keinginan masyarakat. (2) Institusional development; melakukan kegiatan melalui pengembangan pranata sosial yang sudah ada dalam masyarakat. Karna institusi atau pranata sosial masyarakat merupakan daya tamping dan daya dukung sosial.

Participatory; cara ini merupakan suatu 
pendekatan yang umum dilakukan untuk dapat mengali need yang ada dalam masyarakat.

\section{Partisipasi Masyarakat dalam}

Pembangunan Kampung Kamangi

\section{Distrik Tanah Miring Kabupaten}

Merauke

Seperti dalam prinsip-prinsip partisipasi sebagaimana tertuang dalam panduan pelaksanaan pendekatan partisipasi yang disusun oleh Department For International Development (DFID) (dalam Monique, 2004: 106-107) maka hasil yang didapat dari hasil penelitian yaitu sebagai berikut :

\section{Cakupan}

Cakupan adalah semua orang atau wakil-wakil dari semua kelompok yang terkena dampak dari hasil-hasil suatu keputusan atau proses proyek pembangunan.

Pembangunan dikampung kamangi dimulai pada tahun 2016 melalui Musyawarah kampung atau Muskam, Dari hasil wawancara dengan kepala kampung Kamangi menjelaskan program pembangunan rumah bantuan swadaya kampung merupakan keputusan masayarakat melalui Muskam, hal ini berbeda dengan keterangan dari hasil wawancara dengan ketua RW 01 bapak Andreas Dinggon demikian keterangan informan.
Dengan demikian jelas bahwa prinsip cakupan untuk peningkatan pertisipasi masyarakat dalam pembangunan belum ada, perioritas rumah bantuan ADD masih didominasi oleh satu suku tertentu. Keterwakilan suku-suku perintis/ penghuni kampung kamangi belum merata dirasakan sehingga upaya peningkatan partisipasi masyarakat dalam prinsip cakupan belum terwujud.

Kesetaraan dan kemitraan (Equal Partnership)

Pada dasarnya setiap orang mempunyai keterampilan, kemampuan dan prakarsa serta mempunyai hak untuk menggunakan prakarsa tersebut terlibat dalam setiap proses guna membangun dialog tanpa memperhitungkan jenjang dan struktur masing-masing pihak.

Dari hasil penelitian didapat bahwa masyarakat setempat sebenarnya ikut aktif dalam program pembangunan, akan tetapi pemerintah tidak memberikan ruang bagi mereka. Contohnya adalah ketika proses pembangunan rumah bantuan bagi masyarakat, harusnya mereka minta agar tenaga kerja yang digunakan untuk membangun rumah tersebut adalah warga setempat sendiri. Akan tetapi yang terjadi justru yang mengerjakan adalah 
orang dari luar kampung. hal ini yang membuat masyarakat merasa apatis terhadap pemerintah karena secara tidak langsung artinya mereka tidak dipercayakan untuk melaksanakan pembangunan di kampungnya sendiri.

Pemberian ruang terhadap masyarakat untuk turut andil dalam pembangunan di kampung adalah sebuah elemen yang penting dalam terciptanya rasa memiliki oleh masyarakat terhadap segala asset yang ada di kampung. Kesetaraan yang dimaksud bukan berarti masyarakat setempat serta merta diberikan kewenangan untuk membuat semua bangunan rumah bantuan tersebut, akan tetapi mereka diberikan porsi sesuai kompetensi mereka.

Dengan demikian, maka dapat disimpulkan bahwa indikator kesetaraan dan kemitraan belum terwujud dalam pembangunan kampung di Kampung Kamangi.

\section{Transparansi}

Semua pihak harus dapat menumbuh kembangkan komunikasi dan iklim berkomunikasi terbuka dan kondusif sehingga menimbulkan dialog. Dari hasil penelitian menjelaskan Tidak adanya transparansi pemerintah kampung dengan pihak pengelola pertanian atau Gapoktan serta dinas terkait selama ini merupakan gambaran pemerintahan yang kurang terbuka, akibatnya kampung tidak bisa mendapat bantuan alat pertanian. Hal serupa juga terjadi pada saat proses pembangunan infrastruktur di kampung tersebut. Tidak adanya transparansi komunikasi yang baik antara pemerintah kampung dengan masyarakat mengakibatkan masyarakat jadi enggan untuk berpartisipasi dalam setiap pembangunan kampung.

Dengan demikian dapat ditarik kesimpulan bahwa selama ini tidak ada dialog ataupun komunikasi antara kelompok tani dengan pemerintah kampung Kamangi sehingga tidak ada laporan seperti yang di sampaikan kepala kampung.

\section{Kesetaraan Kewenangan (Sharing Power/Equal Powership)}

Berbagai pihak yang terlibat harus dapat menyeimbangkan distribusi kewenangan dan kekuasaan untuk menghindari terjadinya dominasi. Akan tetapi, yang terjadi di Kampung Kamangi adalah segala kewenangan ada di kepala kampung. Hal ini terbukti dengan penjelasan bendahara kampung bahwa ketika dana kampung keluar dana itu dalam tangan kepala kampung, bendahara cuma tanda tangan saja untuk dana keluar, dana kepala kampung yang atur, rekening kepala kampung yang 
pegang bendahara tanda tangan saja, dana-dana kepala kampung yang atur.

Artinya fungsi kesetaraan kewenangan tidak ada untuk bendahara kampung, kepercayaan terhadap bendahara kampung belum ada, seharusnya masalah perbendaharaan sepenuhnya tanggungjawab jabatan, sehingga jelas dominasi terjadi dalam bidang keuangan. Dalam pengambilan keputusan yang tidak melibatkan anggotanya juga terjadi dalam lembaga kampung khususnya Bamuskam demikian penjelasan hasil diskusi kelompok seperti pernyataan tokoh agama sekaligus tokoh pendidikan yang ditujukan kepada ketua Bamuskam dalam menjawab perntanyaan moderator diskusi, demikian penjelasan tokoh agama.

Hal ini menjelaskan bagaimana antara sesama anggota Bamuskam belum memiliki kesetaraan kewenangan yang sama dalam mengambil suatu keputusan. Prosedur usulan tidak selalu tepat adanya dominasi keputusan sepihak oleh Bamuskam menjadi masalah utama partisipasi pada prinsip kesetaraan dalam perencanaan dan pengambilan keputusan Kampung.

Kesetaraan Tanggung Jawab (Sharing Responsibility)
Berbagai pihak mempunyai tanggung jawab yang jelas dalam setiap proses karena adanya kesetaraan kewenangan (sharing power) dan keterlibatannya dalam proses pengambilan keputusan dan langkahlangkah selanjutnya. Indikator ini pun juga belum dilaksanakan dengan baik oleh Pemerintah Kampung Kamangi. Hal ini dapat kita lihat dari Keterangan singkat Informan selaku Kaur Kesra Kampung Kamangi yang belum mendapat kesempatan penuh atas rekanrekan aparat lainnya bahkan pemerintah kampung dalam menyusun programnya, sehingga program bidang Kesejahteraan rakyat tidak pernah mendapat tanggapan bahkan masuk dalam program tahunan kampung sejak 2 tahun berdirinya kampung Kamangi. Ini menunjukan salah satu prinsip partisipasi dalam fungsi kesetaraan tanggungjawab belum terlaksana dengan baik.

Kemampuan sumber daya manusia merupakan kendala utama dalam berpartisipasi untuk pembangunan kampung, apakah itu melalui rencana atau program yang sudah di konsep. Pernyataan tersebut jelas tidak sesuai lagi dengan prinsipprinsip Partisipasi kesetaraan Masyarakat dalam pembangunan Kampung Kamangi. Intinya bahwa 
partisipasi itu dimana partisipasi masyarakat kelompok, masyarakat pendidikan, masyarakat rohani sampai sekarang kan pemerintahan kampung, bagaimana peranan partisipasi pemerintah kampung mengayomi masyarakat ketiga kelompok ini untuk menuju kepada masyarakat yang modern masyarakat yang bisa melindungi diri sendiri mendukung pemerintahan disegala sektor pembangunan, jadi intinya bahwa partisipasi mendapat satu bentuk kebersamaan untuk menuju masyarakat yang bisa mandiri, bertanggung jawab dimana kita berkelompok.

\section{Pemberdayaan (Empowerment)}

Keterlibatan berbagai pihak tidak lepas dari segala kekuatan dan kelemahan yang dimiliki setiap pihak, sehingga melalui keterlibatan aktif dalam setiap proses kegiatan, terjadi proses saling belajar dan saling memberdayakan satu sama lain. Pemberdayaan di Kampung Kamangi sebenarnya telah dicanangkan oleh pihak bamuskam yaitu untuk mengelola 20 hektar lebih lahan pertanian yang tidak beroperasi di Kampung Kamangi.

Upaya ketua Bamuskam untuk mengelola lahan tidur seluas 21 hektar di lingkungan Kamangi merupakan upaya pemberdayaan untuk mensejahterakan masyarakat agar sumber ekonomi masyarakat tidak tergantung pada alam namun sejauh ini belum mendapat dukungan dari pemerintah kampung.

Keinginan ketua Gapoktan agar pemerintah kampung mendukung ekonomi pertanian masyarakat kampung Kamangi dengan memberikan suport berupa dana kelola pertanian namun harapan ketua Gapoktan tidak terwujud sementara dana pemberdayaan ada. Pemerintah kampung mendapat protes dari Satgas dana desa dari Pusat. Akibat pembangunan rumah yang menggunakan ADD, dan tidak mempergunakan untuk kegiatan padat karya seperti pembuatan jalan dan gorong-gorong, belum berpihak pada kepentingan orang banyak. Menurut kepala seksi pelayanan bahwa pemberdayaan merupakan bagian dari tugas bidang 3 yaitu pemberdayaan Kampung.

Menurut kepala seksi pelayanan bahwa dana pemberdayaan sebagian di lempar ke pembangunan perumahan kamasyarakat, ini merupakan kebijakan kepala kampung yang memperrtimbangkan keinginan masyarakat yang meminta untuk pemenuhan perumahan agar lebih di utamakan demikian penjelasan sataf aparatur kampung bidang pelayanan. 
Harapan dan keinginan ketua Bamuskam yang fokus pada sektor pertanian pendidikan dan kerohanian kesehatan mengajak pemerintah kampung agar lebih memperhatikan kedepannya lebih memperdayakan sektor-sektor tersebut sehingga dapat berguna untuk masyarakat kampung.

\section{Kerjasama}

Diperlukan adanya kerja sama berbagai pihak yang terlibat untuk saling berbagi kelebihan guna mengurangi berbagai kelemahan yang ada, khususnya yang berkaitan dengan kemampuan sumber daya manusia. Akan tetapi, kemampuan aparatur kampung khususnya pelayanan masih sangat terbatas yang berkaitan dengan kemampuan SDM aparatur, namun upaya untuk mendapat pembinaan-pembinaan masih terus diupayakan dari pemerintah Kampung. Disisi lain pelayanan Administrasi terus memberikan pelayanan dengan sebaik-baiknya dengan keterbatasan kemampuan SDM aparat. Salah satu hasil wawancara dengan sekertaris kampung dalam partisipasi pelayanan administrasi kampung.

Kemampuan sumber daya manusia masih menjadi kendala dan hambatan dalam pelayanan yang maksimal, namun sebagai sekertaris kampung tetap memberikan pelayanan dengan baik, walaupun tenaga teknis ada mendapat bantuan dari kepala seksi pelayanan Berikut keterangan kepala seksi pelayanan.

Salah satu tugas pelayanan administrasi umum adalah pencatatan dan pendataan KK, KTP dan surat keterangan lain. Upaya pelayanan administrasi adalah bagian dari partisipasi pembangunan bidang pelayanan kampung. Peran pemerintahan dalam menyelenggarakan pemerintahan harus tetap berjalan dan dan memperhatikan kualitas pelayanan guna tercapainya masyarakat yang tertib administrasi dan sejahtera. kepala kampung mempekerjakan tenaga teknis sebagai tenaga pendamping kampung yang sekaligus memberikan pelatihan pengetahuan komputer Aparatur Kampung.

Pihak pemerintah kampung melakukan kontrak kerja kepada tenaga pendamping untuk membantu berpartisipasi dalam pelayanan kampung khususnya administrasi kantor. Tenaga pendamping kampung bertugas membuat laporan pertanggungjawaban (LPJ), kampung yang seharusnya menjadi tanggungjawab Kaur kuangan kampung. Selain itu, tugas lain tenaga teknis seperti 
yang disampaikan sekertaris kampung berikut keterangannya.

Prinsip partisipasi kerjasama merupakan dasar kekuatan dalam menyelenggarakan pemerintahan dan pembangunan. Pandangan ketua RT 02/ RW 01 bapak Kansius Ukurop tentang pelayanan administrasi. Pandangan masyarakat tentang administrasi masih kurang baik dalam pelayanan. Penataan administrasi terkesan begitu-begitu saja tidak ada perubahan selama kampung berdiri sendiri. Walaupun ada rasa kekhawatiran namun informan harus jujur mengakui tentang hal itu.

Memang harus di akui wujud dari partisipasi adalah sebuah kerjasama antara lembaga dengan lembaga pemerintah, lembaga pemerintah dengan individu bahkan inidividu dengan individu. Yang menjadi masalah di Kampung Kamangi adalah tidak adanya kerjasama di dalam mengelola pemerintahan Kampung, baik dari sisi apparat kampung dengan kelompok masyarakat, ataupun dengan masyarakat itu sendiri. Bahkan perhatian pemerintah terhadap ekonomi pertanian tidak ada selama ini, pembangunan tanpa kerjasama tidak akan berjalan baik. Dukungan masyarakat dalam pembangunan akan merupakan unjuk tombak dari sebuah partisipasi aktif dalam meningkatkan kesejahteraan masyarakat.

\section{Kendala-Kendala Partisipasi dalam} Pembangunan Kampung Kamangi

Beberapa kendala partisipasi yang ada dan dihadapi masyarakat Kampung Kamangi dalam pembangunan selama ini antara lain :

\section{Tingkat Pendidikan}

Dikatakan bahwa kondisi Kampung Kamangi adalah kampung baru yang memang banyak kendala dalam merintis kampung tersebut, kendala yang ada selama ini seperti masalah tingkat pendidikan, pendidikan para pejabat Aparatur Kampung rata-rata Sekolah Dasar sehingga mengalami kesulitan dalam mengelolah anggaran Kampung, sebagai Bendahara tetap optimis dalam menjalankan fungsinya. Memang disadari fasilitas perkantoran masih terbatas namun pelayanan dan administrasi tetap harus dijalankan karna Dikatakan sebagai salah satu syarat mutlak untuk berpartisipasi. Pendidikan dianggap dapat memengaruhi sikap hidup seseorang terhadap lingkungannya, suatu sikap yang diperlukan bagi peningkatan kesejahteraan seluruh masyarakat.

\section{Pekerjaan dan penghasilan}


Hal ini tidak dapat dipisahkan satu sama lain karena pekerjaan seseorang akan menentukan berapa penghasilan yang akan diperolehnya. Pekerjaan dan penghasilan yang baik dan mencukupi kebutuhan sehari-hari dapat mendorong seseorang untuk berpartisipasi dalam kegiatan-kegiatan masyarakat. Pengertiannya bahwa untuk berpartisipasi dalam suatu kegiatan, harus didukung oleh perekonomian yang mapan. Sedangkan mayoritas masyakat Kampung Kamangi adalah berkebun dan berburu yang mana penghasilan yang didapat tidak menentu. Hal ini membuat mereka lebih banyak menghabisakn waktu saat siang hari dihutan dan lading dari pada turut serta dalam pembangunan kampung.

\section{Kesadaran Masyarakat}

Masyarakat kampung memiliki karakteristik masyarakat yang berbedabeda, salah satunya adalah perbedaan generasi (usia) sangat menentukan kesadaran masyarakat untuk berpartisipasi dalam program masyarakat. Kesadaran masyarakat di Kampung Kamangi masih banyak yang merasa mencari kebutuhan untuk makan sehari-hari dihutan dan di ladang lebih penting dari pada turut serta dalam pembangunan kampung. Salah satunya adalah sulitnya mengumpulkan masyarakat untuk melakukan musyawarah kampung sebagai bahan untuk pengambilan keputusan. Padahal di ruang tersebutlah masyarakat dapat menyampaikan aspirasi dan kebutuhannya.

\section{Tidak Adanya Akses}

Kegiatan pemerintahan di Kampung Kamangi saat ini tidak kerjasama yang baik antara sesama RT, RW Bamuskam bahkan pemerintah Kampung dan aparatnya, pernyataan itu dipertegas ketika kegiatan diskusi kelompok bahwa kerjasama dan dukungan dari pemerintah tidak ada sama sekali, harapan ketua RT 002 tersebut kirannya ada kerjasama yang baik dalam membangun Kampung baik secara fisik maupun pikiran dan saran, harus ada duduk bersama antara sesama RT dengan pemerintah kampung membahas rencana pembangunan kedepan. Karna informasi dan masukan yang bersifat mufakat akan sangat berguna dalam partisipasi masyarakat untuk membangun Kampung, sesuai hasil musyawarah tersebut diharapakan memunculkan ide dan gagasan baru yang cemerlang untuk masayarakat banyak sehingga tidak terkesan individual atau kepentingan oknum tertentu maupun kelompok tertentu bahkan di sinyalir menjadi kepentingan kepala Kampung, 
disimpulkan dalam kategori pelanggaran tipe prinsip-prinsip partisipasi khususnya Kesetaraan Kewenangan (Sharing Power/Equal Powership) : Berbagai pihak yang terlibat harus dapat menyeimbangkan distribusi kewenangan dan kekuasaan untuk menghindari terjadinya dominasi. Artinya antara RT, RW Bamuskam dan pemegang kekuasaan harus seimbang dalam menyalurkan wewenang dan kekuasaan dilingkungannya sehingga tidak terjadi dominasi tunggal pengambil kebijakan dalam hal ini Bamuskam atau Pemerintah Kampung.

\section{Upaya peningkatan partisipasi dalam}

\section{pembangunan Kampung Kamangi}

Tiga prinsip dasar dalam menumbuhkan partisipasi masyarakat Kampung agar ikut serta dalam pembangunan (Marzali, 2003 dalam Sahidu, 1998) :

Learning Proces (learning by doing);

Learning Proces yaitu proses kegiatan dengan melakukan aktifitas proyek dan sekaligus mengamati, menganalisa kebutuhan dan keinginan masyarakat. Dari hasil penelitian didapat bahwa proses pembelajaran memang harus dimulai dari sebuah kekurangan, kelemahan bahkan kesalahan yang telah terjadi dimasa lalu dan sekarang, ini merupakan awal proses belajar dari sebuah kekurangan. Mendengar aspirasi dan keinginan masyarakat juga merupakan sebuah proses pembelajaran seperti yang di katakan kepala Kampung bahwa masyarakat ingin agar pembangunan rumah masuk dalam program kerja pemerintah Kampung, tentu ini juga merupakan suatu keinginan yang kuat dari masyarakat, entah kenapa masyarakat selalu ingin memasukan program pembangunan rumah setiap tahunnya tentunya dapat disimpulkan bahwa memang kebutuhan utama masyarakat Kamangi saat ini adalah perumahan layak huni. Kemudian keinginan pemerintah kampung khususnya kepala urusan perencanaan untuk segera mewujudkan program perumahan memang cukup kuat, bahkan beliau mengajak masyarakat agar menyampaikan aspirasi melalui Bamuskam tidak secara individu, prosedur penyampaian dikatakan masyarakat harus mengundang ketua Bamuskam untuk duduk bersama membahas apa keinginan masyarakat kedepan.

Dari kedua pernyataan informan tersebut jelas dikatakan sangat erat kaitannya dengan sebuah teori yang sudah di sampaikan oleh Marzali, 2003. Artinya teori ini sangat relevan dengan 
pernyataan dari kedua tokoh Pemerintah Kampung Kamangi.

Institusional Development;

$$
\text { Institusional Development }
$$

adalah melakukan kegiatan melalui pengembangan pranata sosial yang sudah ada dalam masyarakat. Karna institusi atau pranata sosial masyarakat merupakan daya tampung dan daya dukung sosial.

Institusi merupakan wadah organisasi yang cukup kuat dalam sebuah kelompok. Kelompok tanpa sebuah institusi bagaikan keluarga tanpa rumah artinya setiap kelompok orang dan komunitas perlu sebuah institusi yang melindungi, mewadahi bahwan mengatur segala sesuatunya.

Pemerintah Kampung Kamangi telah memiliki beberapa institusi yang di akui keberadaannya, seperti keberadaan lembaga RT, RW, Bamuskam bahkan kelompok tani, dan kelompok peramu. Mengapa kelompok oranisasi kecil ini dikatakan sebuah institusi atau pranata sosial, karna institusi inilah yang paling dekat dengan masyarakat dan merupakan tangga pertama sebuah aspirasi bisa sampai ke pemerintahan pusat. Institusi RT, RW Bamuskam dan Gapoktan merupakan sarana dan bahan dalam mencetuskan sebuah pemikiran dari tingkat bawah, fungsi pranata sosial ini memberikan ruang dan kekuatan dalam memberikan sebuah ide bahkan keinginan yang tulus dari seorang masyarakat ditingkat bawah.

Sehingga dalam proses diskusi kelompok para tokoh agama, adat, masyarakat bahkan pemerintah Kampung menekankan agar setiap informasi dan program dari pusat atau pemerintah Kampung agar di sampaikan melalui RT sehingga pemerintah Kampung tidak langsung menuju masayarakat tetapi melaui RT. Ini merupakan cermin bahwa RT mempunyai kekuatan lembaga di tingkat bawah. Senada dengan ketua Bamuskam juga mengingatkan agar yang namanya RT agar membantu pemerintah dan kelompok tani yang ada di Kampung, contonhnya RT harus mengajak masayarakat agar mendukung program pertanian Kampung hal ini disampaikan oleh ketua Bamuskam Kampung Kamangi bapa Robertus Kandemu saat beliau memberikan kesimpulan akhir tentang harapan dan keinginan masyarakat terhadap pembangunan Kampung kedepan. Pernyataan tersebut disampaikan di tengah-tengah diskusi kelompok. Pendapat serupa juga disampaikan oleh bapak RW 001 Andreas Dinggon bahwa fungsi pemerintah adalah mengatur semua 
institusi yang ada di Kampung, bagaimana hubungan dan kerjasama antara RT dengan kepala Kampung, kepala Kampung dengan Bamuskam harus selalu di tingkatkan demi peningkatan partisipasi pembangunan Kampung kedepan yang lebih baik. Ketiga pernyataan ini tentunya mendapat dukungan secara teori dari Marzali 2003, bahwa pengembangan pranata yang sudah ada di masyarakat merupakan kekuatan sosial yang cukup tinggi, artinya dukungan bagi sebuah institusi pranata sosial merupakan syarat mutlak dalam peningkatan partisipasi masyarakat.

\section{Kesimpulan}

Dari hasil penelitian disimpulkan partisipasi masyarakat dalam pembangunan Kampung Kamangi dilihat dari indikator prinsip-prinsip partisipasi masyarakat yaitu; cakupan, kesetaraan dan kemitraan, kesetaraan kewenangan, kesetaraan tanggung jawab, pemberdayaan, dan kerjasama mendapatkan hasil yang masih belum baik.

Hal ini ditandai dengan indicator cakupan masih belum terlaksana dengan baik. Yaitu penyusunan program pembangunan kampung hanya dibahas oleh beberapa oknum saja dan tidak melibatkan seluruh elemen masyarakat.
Kemudian masih minimnya ruang yang diberikan oleh pemerintah kampung kepada masyarakat. Selain itu, mata pencaharian masyarakat setempat yang mengharuskan pergi ke ladang dan hutan membuat pemerintah kampung sulit memberdayakan mereka sehingga indikator pemberdayaan juga masih belum terlihat disana.

Kendala partisipasi yang ada di masyarakat kaitannya pembangunan Kampung Kamangi diantaranya adalah masih kurangnya kesadaran masyarakat akan pentingnya terlibat dalam setiap pembangunan di kampung, sehingga mereka lebih memilih untuk mencari kebutuhan hidup mereka masuk ke hutan dari pada ikut dalam programprogram pembangunan kampung. Kendala yang berikutnya adalah masih minimnya ruang yang diberikan oleh pemerintah kampung kepada masyarakat yang akan ikut berpartisipasi.

Dengan melihat hasil penelitian di atas, maka yang dapat penulis sarankan adalah emerintah kampung memberi ruang untuk melibatkan semua pihak dalam penyelenggaraan perencanaan kampung mulai tokohtokoh adat, tokoh agama, RT, RW Bamuskam dan aparatur kampung serta semua elemen masyarakat terutama 
dalam penyusunan program perioritas dalam pembangunan kampung hinga pelaksanaanya.

Selain itu, perlunya peningkatan kapasitas Lembaga-Lembaga Masyarakat yang ada seperti : Lembaga Adat, Lembaga Agama, Kelompok-Kelompok Tani, Kelompok Peramu, sehingga aspirasi mudah terwadahi. Peningkatan keningkatan kesadaran masyarakat juga menjadi tanggung jawab pemerintah kampung demi tercapainya sebuah pelibatan diri disetiap pembangunan yang telah direncanakan pemerintah.

\section{Daftar Pustaka}

Anggraeni, L. 2009. Factors influencing participation and credit constraints of a financial selfhelp group in remote rural area: The case of ROSCA and ASCRA in Kemang Village West Java. Journal of Applied Sciences, 1: 111.

Irawan, A. (2019). Model Partisipasi Masyarakat Dalam Program Kampung Siaga Aktif di Kampung Salor Indah Distrik Kurik Kabupaten Merauke, 5(1), 40-60. Retrieved from http://ejournal.umm.ac.id/index .php/sospol/article/view/6990
Luigi Bobbio. 2018. Designing effective public participation. Policy and Society. Published by Informa. https://doi.org/10.1080/14494 $\underline{035.2018 .1511193}$

Mathew B. Miles, A. Michael Huberman. \& Saldana Johnny. Qualitative data analysis: a methods sourcebook, Third Edition. 2014. United States of America: SAGE Publications

Mikkelsen, B. 2011. Metode Penelitian Partisipatoris dan Upaya Pemberdayaan. Yayasan Obor Indonesia: Jakarta

Murray G. Ross with B.W. Lappin Community organization : theory, principles, and practice. Harper \& Row : New York.

Peraturan Pemerintah Nomor 45 Tahun 2017 tentang Partisipasi masyarakat dalam penyelenggaraan pemerintahan Daerah.

Pratchett, Lawrence. Gerry, Stocker. Vivien, Lowndes. 2009. Empowering communities to influence local decision making ( $A$ systematic review of the evidence). University

Southampton : United Kingdom. 
Soetomo. 2008. Strategi-Strategi

Pembangunan Masyarakat.

Pustaka Pelajar : Yogyakarta

Quick, Kathryn S. Feldman, Martha S.

2011. Distinguishing

participation and inclusion.

Journal of Planning Education

and Research

Undang Nomor 6 Tahun 2014 tentang

Desa

Slamet, M. 2003. Pembangunan

Masyarakat Berwawasan

Partisipasi. Surakarta : Sebelas

Maret University Press

Sumampouw, Monique. (2004).

“Perencanaan Darat-Laut yang

Terintegrasi dengan

Menggunakan Informasi Spasial

yang Partisipatif." Jacub Rais, et

al. Menata Ruang Laut Terpadu.

Jakarta: Pradnya Paramita. 91-

117.

Isbandi, R.A. 2007, perencanaan partisipatorisberbasis asset komunitas: dari pemikiran menuju penerapan. Depok: FISIP UI Press. 